\begin{tabular}{c}
\hline KEMAS 14 (1) (2018) 41-48 \\
Jurnal Kesehatan Masyarakat
\end{tabular}

\title{
Evaluation of Administrative Service Quality Towards JKN Patient Satisfaction
}

\author{
Molina Indarwati ${ }^{1 凶}$, Phan Thien Phuoc ${ }^{2}$ \\ ${ }^{1}$ Department Public Health, Universitas Negeri Semarang, Indonesia \\ ${ }^{2}$ Hongbang International University, Vietnam
}

\section{Article Info}

Article History:

Submitted May 2018

Accepted July 2018

Published July 2018

Keywords:

Patient Satisfaction,

JKN, Quality of Service

\section{DOI}

https://doi.org/10.15294/

kemas.v14i1.14915

\begin{abstract}
Based on BPJS Kesehatan data, there was a decrease in Participant Satisfaction Index by $0.3 \%$ in 2016. The number of outpatient visits in RSUD KRT. Setjonegoro Wonosobo has decreased in 2016. Based on preliminary study, there were problems mainly related to health services provided by RSUD KRT. Setjonegoro Wonosobo. The purpose of this study was to determine how the quality of administrative services affect the satisfaction of JKN patients. This research used qualitative research methods. Data collection was conducted using observation and interview techniques. The results showed that the quality of administrative services in RSUD KRT. Setjonegoro seen from the dimensions of tangibles, reliability, responsiveness, assurance, and empathy is good. All the main informants were satisfied enough with the health services provided by the hospital. The advice given was to improve the performance in by conducting regular evaluation of the services provided.
\end{abstract}

\section{Introduction}

Hospital is an organization that provides service, therefore high quality service deliverance is required. If the patients is not satisfied by the service provided by the hospital, they will not come back for another visit. Improving and maintaining the quality of service is the first priority in hospital healthcare management. Several benefits of maintaining a good quality of service are as follows: increases the effectivity and efficiency of the health service, increases people's acceptance towards the hospital health service, and protects the implementation of healthcare service from lawsuit (Firdaus \& Dewi, 2014).

There are satisfaction indicators that can be used to assess the quality of the service. Pasuraman, Zeithaml, and Berry (Linimol \& Nair, 2016) divided the dimension of quality of service into several components. These components were known as ServQual (Service Quality). ServQual consisted of the following five dimensions: reliability, assurance, tangibles, empathy, and responsiveness.

According to Pouragha \& Zarei (2016), patient satisfaction is the positive or negative attitude that reflects the patient's feeling towards the service. The quality of service is related to cognitive assessment, while patient satisfaction is related to affective assessment. The difference between quality of service as cognitive construct and patient satisfaction as emotional construct 
showed causal relationship, where the quality of service is the predictor of patient satisfaction. Several studies have been performed to understand the relationship between quality of service and patient satisfaction. No wonder, the results showed that the high quality of service lead to higher patients satisfaction. The quality of service is the proper appearance (that related to the standard) of the intervention, which is known to be safe, produce good result to the concerned people, and is known to produce impact towards mortality, morbidity, inability, and malnutrition (Sondari \& Raharjo, 2017).

Administration service in the outpatient unit is the most important part of hospital health system, the main gate for patients in the inpatient unit, and one of the first contacts between the patient and the hospital. Therefore, quality of administration service in the outpatient unit gives significant contribution to general patient impression towards hospital service. Moreover, compared to the other hospitals, outpatient center grows faster and the income from this unit is higher than the inpatient unit. Therefore, the ability of the hospital to provide high quality service in the administration section will be important for long-term continuity of the hospital (Pouragha, 2016). Hospital administration is a process of planning, organizing, briefing, monitoring, coordinating, evaluating the source, procedure, and ability to fulfill the demand towards health, care, and healthy environment by providing and organizing several health efforts for individual, family, group, or the society (Badan Penyelenggara Jaminan Sosial Kesehatan, 2013).

The JKN program is aimed to guarantee the member to get the benefits of healthcare and protection in order to fulfill their basic health needs. Through this program, basic needs of community health in Indonesia is expected to be fullfiled. Therefore, community health quality in Indonesia can be increased, which is in line with the goals of National Health System (SKN). The JKN program guarantee several health cares in several health facilities, which cooperate with BPJS. Indicator of success of BPJS or JKN program is the community satisfaction level (Badan Penyelenggara Jaminan Sosial Kesehatan, 2013). Satisfaction is assessed from the hospital service and from the doctors as the main subjects.

According to the data from BPJS Kesehatan through external survey, there was a decrease in BPJS member satisfaction index as much as $0.3 \%$ in 2016. The BPJS member satisfaction index in 2015 and 2016 were $78.9 \%$ and $78.6 \%$, respectively. The decrease of the index was especially driven by the decrease of contact from the advance referral health care facility (FKTRL). The BPJS Kesehatan also mentioned several complaints of BPJS member toward the service from healthcare facilities in 2016, such as the long queue in the facilities, the patients not examined by the doctor, the drugs were often out of stock, the limitation of drugs prescription, the lack of information about the type of service in the hospital, and the patients having to visit the hospital over and over again (Badan Penyelenggara Jaminan Sosial Kesehatan, 2016).

KRT Setjonegoro General Hospital in Wonosobo is a type $\mathrm{C}$ general hospital, which became the main referral hospital and the only government hospital in Wonosobo Regency. According to the preliminary study, the patient visit in this hospital is more crowded and the hospital have higher average amount of visitor compared to the other hospitals in Wonosobo. One of the reasons why patients choose KRT Setjonegoro General Hospital was because of its better and more complete facilities compared to the other hospitals. However, the huge amount of patients created several problems, such as uncomfortable environment, not optimal healthcare services, long duration of queue, and not yet satisfying healthcare services. These unsatisfying services contribute to the decrease of the amount of outpatient visits in 2016. According to the data of outpatient visit from 2010-2014 and the medical record of KRT Setjonegoro General Hospital, there was 123,048 and 117,721 visits in 2015 and 2016, respectively. The visit was decreasing as much as $5.327 \%$.

Moreover, several JKN patients complaint about the long duration of registration process, complicated registration process, and the lack of communication between the patients and the administration officer. Therefore, the miscommunication often occurred and made 
patients uncomfortable. Several patients were still confused about the referral system in BPJS Kesehatan. There were also patients that complained about the difference of treatment between JKN and non-JKN patient, especially the recipient of contribution assistance (PBI) class. Furthermore, according to the gathered information, we also found other problems related to the healthcare services given by KRT Setjonegoro General Hospital. This study was aimed to understand the impact of quality of administration service towards JKN patient satisfaction in outpatient unit of KRT Setjonegoro General Hospital in Wonosobo.

Method

This study was focused on the quality of administration services seen from tangible, reliability, and responsiveness, assurance, and empathy dimensions towards the JKN patient satisfaction in KRT Setjonegoro General Hospital outpatient unit. The method used in this study was qualitative-descriptive method with purposive sampling technique. Respondents were $10 \mathrm{JKN}$ patients of outpatient unit, which had visited the outpatient unit for at least 3 times, $\geq 16$ year old of age, and able to communicate well. Furthermore, triangulation interviewees consisted of 4 people from the family or friend of the patient, administration officer, hospital manager, and BPJS officer. The family or friend of the patient had to visit the hospital for a minimum of 3 times before the study, available to accompany the patient in the time of the study, and agreed to become an interviewee. Administration officer included in this study was a permanent employee, had handled the JKN patient before, had a minimum of 6 months working experience, and agreed to become an interviewee. BPJS Officer included in this study was a permanent employee, had a minimum of 1 year working experience, and agreed to become an interviewee. Hospital manager included in this study had to agree to become an interviewee. We used the triangulation from the family/friend of the patient, administration officer, BPJS officer, and hospital manager because they were closed to the main subjects and had impact or related with the illustration of service given by the hospital. Information from the triangulation interviewee will be matched with the information obtained from the main subjects. Therefore, we expected that the information obtained from this study were valid.

Secondary data was obtained from literature study. In this study, secondary data was obtained from the documents of KRT Setjonegoro General Hospital, such as hospital profile, data of patient visit from medical record, and patient satisfaction index. Data collection technique was observation and interview. We performed direct observation, which focused on the administration service for JKN patient in KRT Setjonegoro General Hospital outpatient unit.

Instruments used in the observation were observation checklist, cellphone camera, and stationaries. The type of interview performed in this study was an in-depth interview. Instruments used in the interview were interview guideline, cellphone recorder, and stationaries.

The procedure used in this study was by giving the illustration of the entire plan, data collection, data analysis, data interpretation, and report writing. The stages of this study including preliminary stage, implementation of the main study, and data analysis. Preliminary stage including the licensing process of preliminary study, preliminary study, proposal preparation, interview guideline preparation, and licensing process of the main study. The stage of study implementation including the activities performed before and after the main study. This stage including in-depth interview using structured and un-structured interview, field observation in study environment, collection of secondary data, and the documentation of the study. Data analysis stage including analysis, creating conclusion, and writing the report.

Examination of the data validity in this study used dependability test and credibility test using triangulation technique. Dependability test was performed by independent auditor or guide to audit the entire activities of the study (Febriana \& Stefanus, 2013). In this study, the auditor was our lecturer. Triangulation is a technique to check the data credibility by checking the obtained data from several sources (Musramadoni, 2016). In this study, in order to test the credibility of the data about the evaluation of quality of administration service 
given by the hospital, the collection and test of the data were performed on the administration staff in KRT Setjonegoro General Hospital outpatient unit.

Method of data analysis used in this study was used qualitative approach. Analysis method including data processing with data reduction, data presentation, and conclusion. Data reduction means to summarize, to choose the main data, to focus on the important thing, to search for a theme and pattern. Data reduction will provide a clear illustration and ease us to perform the next data collection. After data reduction, we performed data presentation. Data presentation in qualitative study can be presented in summary, graphic, and relationship between categories. Data in qualitative study was generally presented in narrative text. The next step was verification. Verification in qualitative study is a new invention that had never been done before. These founding can be a description or illustration of the object, which were not clear before. Therefore, these object became clearer and can be related causally, interactively, hypothetically, or theoretically. Early conclusion is still temporary and can be changed if there is no strong evidence, which is collected from the next data collection. However, if the conclusion of the early stage is supported by the valid and consistent evidence, this conclusion is credible.

\section{Result and Discussion}

This study was performed in KRT Setjonegoro General Hospital outpatient unit. This type $\mathrm{C}$ hospital is located in the center of Wonosobo regency with 246 beds capacity. It has $7445 \mathrm{~m}^{2}$ of total area, which are divided into $1356 \mathrm{~m}^{2}$ and $6090 \mathrm{~m}^{2}$ of east area. The size of the entire building area was $5207.7 \mathrm{~m}^{2}$. The building of the hospital was divided into building A (4 floors), building $B$ (4 floors), building C (3 floors), building D (2 floors), building $\mathrm{E}$ (1 floor), and west building (4 floors). The location of KRT Setjonegoro General Hospital is in the center of a crowded area, besides a traditional and modern market, center of the government, center of education, and is surrounded by a dense settlement. This position is strategic to develop a hospital, which functions as a healthcare provider, especially as the referral facility for other healthcare facilities in Wonosobo and other regencies. KRT Setjonegoro General Hospital has a vision to become the most superior, trusted, and to have the highest quality of service. Meanwhile, the missions of this hospital is to provide healthcare, which focuses in the patient according to the national standard. KRT Setjonegoro General Hospital was built in 1930 as Zending Zienken Huis. In the next 15 years, there were three changes of the leader of the hospital. After the independency of Republic of Indonesia in 1945, Zending Zienken Huis was submitted to the Indonesian government through the ministry of health. Since 1948 until 1987, this hospital was appointed as general hospital and was managed by the government of Central Java Province. In that time, there were six changes of the hospital leader. In 1987, Wonosobo General Hospital was submitted to the government of Wonosobo Regency as the regional general hospital. The establishment of the type $\mathrm{C}$ of the hospital was through the decisions by the regent of Wonosobo number 061.1/035/1983. This hospital became a self-financing unit in 2000 after the regional regulation number 13 year 2000 was published. Furthermore, this hospital became regional hospital agency in 2001 after regional regulation number 26 year 2001 was published. The name KRT Setjonegoro was given by the regent decision letter number $445 / 42 / 2007$ in $16^{\text {th }}$ February 2007. Until now, Setjonegoro General Hospital still need legality in the form of regional regulation (PERDA) in order to maintain the usage of Setjonegoro as the official name in the hospital administration. The name of KRT Setjonegoro was the name of the first regent of Wonosobo.

The main interviewee or informant in this study was the National Health Insurance (JKN) patient, who had visited the outpatient unit of KRT Setjonegoro General Hospital for a minimum of 3 times. The number of the interviewees was 10 , who had met the criteria of the study. The amount of these interviewees had provide sufficient data for the study. The characteristics of the main informant were presented in the following table:

According to the table above, the number of female informants was larger (7 persons) than the number of male informants (3 persons). According to the age, the youngest 
Table 1. Characteristic of the Main Informants

\begin{tabular}{|c|c|c|c|c|c|c|}
\hline No & Informants & Gender & Age & Education & Employment & JKN status \\
\hline 1. & 1 & Male & 61 & $\begin{array}{l}\text { Junior High } \\
\text { School (SMP) }\end{array}$ & Retired civil servant & Non PBI \\
\hline 2. & 2 & Female & 22 & SMP & Housewife & PBI \\
\hline 3. & 3 & Female & 61 & $\begin{array}{l}\text { ElementarySchool } \\
\text { (SD) }\end{array}$ & Merchant & Non PBI \\
\hline 4. & 4 & Female & 40 & SD & Factory worker & PBI \\
\hline 5. & 5 & Male & 60 & SD & Factory worker & Non PBI \\
\hline 6. & 6 & Female & 53 & $\begin{array}{l}\text { Senior High } \\
\text { School (SMA) }\end{array}$ & Housewife & Non PBI \\
\hline 7. & 7 & Male & 60 & SMP & Entrepreneur & Non PBI \\
\hline 8. & 8 & Female & 50 & SD & Housewife & Non PBI \\
\hline 9. & 9 & Female & 58 & SD & Housewife & Non PBI \\
\hline 10. & 10 & Female & 31 & SD & Housewife & PBI \\
\hline
\end{tabular}

Source: Primary Data

informant was at 22 years old, and the oldest one was at 61 years old. Based on education level, we found that 6 persons finished elementary school, 3 persons finished junior high school, and one person finished senior high shool. Based on the employment, one person was a retired civil servant, 5 persons were housewives, one person was a merchant, and the 2 others were factory workers. Based on the JKN member status, there were 3 persons of PBI (recipient of contribution assistance) and there were 7 persons of non-PBI.

Triangulated informants were the interviewees group for a cross-check purpose towards facts gathered, also for a matching purpose towards the information from the main informants. Based on this study, we described the characteristics of the triangulated informants in the following table.

Based on the table above, there were 4 triangulated informants which consisted of 4 female informants and one male informant, where the youngest was 34 years old and the oldest was 60 years old. Based on the education level, there was one informant with junor high school degree, there were 2 informants with a bachelor degree, and the other had diploma 3 degree.

The perception of the National Health Coverage (JKN) participant-patients on the administrative service quality in RSUD KRT
Setjonegoro Wonosobo was generally reflected on the patients' experiences and knowledges since accessing for JKN registration in the hospital, including their appraisal on the tangible, reliability, responsiveness, assurance, and empathy dimensions of the administration officers. In depth interview resulted that the ten main informants understood the administrative services process held in RSUD KRT Setjonegoro Wonosobo. The main informants explained about the process of administrative service in the registration locket that started from the patients that picked up the queue numbers by pressing queue button. When the officer called the queue number, patient went to registration locket. Patient showed the check up card, reference letter, and BPJS card photocopy. This finding was consistent with the statement from the triangulated informants in the administrative service that the registration plot started from queue number pickup by pressing the queue button, then patients stayed in the waiting room for the queue. Then, patients completed the administrative requirements, such as showing checkup card, reference or control letter, and the photocopy of BPJS card. If the requirements were fulfilled, patients went to the clinics to get examination.

Based on the in depth interview with the ten main informants on the tangible dimension, the result showed that the waiting 
Table 2. Characteristics of the Triangulated Informants

\begin{tabular}{|c|c|c|c|c|c|}
\hline No. & Informants & Gender & Age & Education & Occupation \\
\hline 1. & Daryanti & Female & 60 & SMP & Main informant's family \\
\hline 2. & dr. Handoko Sulistiyo & Male & 43 & Bachelor & $\begin{array}{l}\text { Head of Unit for National Social } \\
\text { Coverage Administrator (PJSN) }\end{array}$ \\
\hline 3. & dr. Pratiwi Amindari & Female & 36 & Bachelor & $\begin{array}{l}\text { Head of Medical Services Section } \\
\text { Administration officer }\end{array}$ \\
\hline 4. & $\begin{array}{l}\text { Widya Listyaningsih, } \\
\text { A.Md. }\end{array}$ & Female & 34 & Diploma 3 & \\
\hline
\end{tabular}

Source: Primary Data

room was clean and comfortable. The office boys were diligent to clean up and tidy up the bench for patients. The infrasturcutre in the waiting room were also well available, such as television for reducing boredom and the numerous amount of seatings for patients. The main informants also provided response on the appearance of the administration officers in RSUD KRT Setjonegoro Wonosobo. They explained that their appearace were neat, polite, and uniformed. Also, the number of administration officers was adequate. Some of the informants did not know the exact number of the officers, but they assumed that the number was sufficient due to the fluent services. It was consistent with the triangulated informants' statement that about the number of the administration officer was 22 persons, consisted of 11 persons in the outpatient registration, 8 persons in the emergency unit registration, and 3 persons in the medical record. This number was sufficient and was in line with the SOP. They also explained that the uniform corresponded with the regulation in RSUD KRT Setjonegoro Wonosobo, in which there wore different uniforms in each day.

This was important because one of the reasons for customer to access service was by looking at the tangible values. If it looks good, then customer would have trust and comfort to utilize the service. Zeithmal dan Bitner in Sondari \& Raharjo (2017) stated that health industry, generally, was identical with the cleanliness and tidiness, health instruments comprehensiveness, and the availability of whole and comfortable facilities was crucial for patients.

Dimension of reliability related to the company's ability to give accurate service since the first time without mistakes in delivering the service corresponding the time agreed. A hospital is called reliable when the process of patient admission was fast and the administrative and payment procedure were practical, the intervention was quick and accurate towards examination and treatment, laboratory tests, doctor visits, and the nursing were appropriate, and also results reporting was fast (Zaim et al., 2010). In this case, patients' need was to gain recovery from illness that required precise diagnosis and treatment.

The research result on reliability dimension of administration officer in serving patient was, based on all main informants, the officer serving patient according to the queue number. Patient should come earlier to pick earlier number queue. Therefore patient who came earlier got early service. The queue number taking started at $06.00 \mathrm{WIB}$, while the registration locket started operating at 07.00 WIB. According to observation, waiting time needed was 10-15 minutes. This duration depends on the total number of patients visit in RSUD KRT. Setjonegoro Wonosobo. But, the main informants assumed that the administration officers had provided quick service, only the large number of patients caused some delays. They also stated that the procedure of patient admission was organized. This was consistent with the triangulated informants statement, that the officer in registration served about 2-5 minutes for each patient, started from registration in the locket until accessing the clinics. But, it would need additional time in the process if the patient was a first-time in accessing the service so the patient did not 
comprehend the procedure well. It led the officer to take time to create checkup card for the patient and to explain the plot. According to health Minister's Decision (Keputusan Menteri Kesehatan) No. 129/Menkes/SK/II/2008 about Minimum Service Standard in Hospital, waiting time should be $\leq 60$ minutes. This standard was the minimal condition expected in order for a hospital to serve well. During the study, RSUD KRT Setjonegoro Wonosobo had been implementing automatic system (button press) to get queue number, with the machine having two buttons: red button for BPJS patients, and green button for Non-BPJS patients. Therefore, this system could ease all patients and manage the time efficiently. Quality of service, if managed well, would affect positively on the customer satisfaction and loyalty to utilize the service, where the reliability was one of the five dimensions of service quality used by customer in evaluating quality of service.

Based on the research on responsiveness dimension of administration officers, the result was good. The officers provided information about the plot in a smiling attitude, greeting the patients, ready to explain information to educate patients. According to the main informants, the administration service had improved, the officers were responsive toward patients' complaints, for example when some patients complained about the waiting time, then the officer provide understanding to be patient until the officer call their queue numbers. The triangulated informant (the patient's family or the family of the main informant that always accompany patient to get treatment in the hospital) confirmed this issue that the officers were kind and friendly. Besides, the administration officer that incuded as triangular informants added information about the principal attitude for every officer should have, which were the attitude of smile, greeting, friendly, nice, and politeness. The officers should behave nicely in facing and handling the diversity of patient attitude.

Regarding the officer attitude in responding to the patient complaints, Head of PJSN Unit in RSUD KRT Setjonegoro Wonosobo explained that they accomodated all kind of complaints. The response would be suited based on the variety of complaint and the
SOP. For the hospital, patients' complaint was a bridge to improvement in managing the quality of service in the hospitals.

The responsiveness from the officer was essential in a health service, the indicator was sense of responsiveness and rapidness of the officer to see their surrounding situation and the decision making to confom with. Thus, patient would feel secure and comfortable with the service, and it could improve the patient satisfaction and good appraisal on the service. It was consistent with the study of Sulayman (2012) which explained that the dimension of responsiveness possessed a significant positive impact toward customer's satisfaction, and responsiveness correlated to the willingness, capacity of the officer to help and to response the patient's order, and to confirm the time of whenever the service and responsive service given. Responsiveness compares expectation and comfort towards giving resolution for customer complaint appropriately and precisely (Firdaus \& Dewi, 2014).

The research on assurance dimension resulted that the main informantas explained that all officers were educated and worked appropriately based on competency. The officers did the job in a nice and polite attitude. The in-depth interview with the triangulated informants supported this finding, that the Head of Section General and Service Section stated that according to Minimum Service Standard (SPM) RSUD KRT Setjonegoro, each staffs and officers should undergo a minimum of 20 hours of training annually. The training was an internal training, such as in-house training, which was an indoor training with internal or external speaker, and external training such as workshop and seminar. The objective of the training was to achieve well educated and well trained staffs to improve the human resources quality in RSUD KRT Setjonegoro.

Dimension of empahty correlated to the company ability to understand the customers' problem and to act friendly towards customer. The hospital would have a dimension of empathy if they were concerned about the patient complaints and needs, acted indiscriminately, and put symphaty on patients (Sulayman, 2012). Based on research result on dimension of empathy, all main respondents stated that 
the officer attitude was attentive enough to the patient. The officer showed a responsiveness on every complaint, provided explanation and understanding to the patient, and became patient and respectful to the patient especially the elderly. For example, the officer was ready to escort elderly patient to clinics. Moreover, the officer was also fair and indiscriminate between BPJS and Non-BPJS patient or rich and poor patient.

\section{Conclusion}

According to the research result on the quality administration service towards satisfaction level of JKN patient in outpatient service of RSUD KRT Setjonegoro Wonosobo, we can conclude that based on informants characteristics, the majority of JKN outpatient in RSUD KRT Setjonegoro Wonosobo ranged from 22 to 61 years old. Female JKN patients dominated the male ones and the majority of them had elementary school degree. Based on occupation, most of them were housewives, and the majorty of JKN member status was Non PBI. The quality administration service in RSUD KRT Setjonegoro based on the dimensions of tangibles, reliability, responsiveness, assurance, and empathy was good. Administrative service given by the administration officers had some improvements compared to the previous period, which were being friendly, polite, responsive, reliable, educated, caring, and empathetic in providing services. Physical condition was clean, neat, and comfortable. The infrastructure was adequate enough. In addition, the nuber of administration officer was assumed to be sufficient and accommodating to the SOP. The appearance of the officers was neat, polite, and uniformed. All main informants felt fairly satisfied with the health service in RSUD KRT Setjonegoro Wonosobo.

\section{References}

Badan Penyelengaran Jaminan Sosial Kesehatan, 2013. Panduan Layanan bagi Peserta BPIS Kesehatan. Jakarta: Badan Penyelenggara
Jaminan Sosial Kesehatan.

Febriana, A. \& Stefanus S., 2013. Mutu Pelayanan Kesehatan Berdasarkan Dimensi Dabholkar di Ruang Rawat Inap Penyakit Dalam. Jurnal Administrasi Kesehatan Indonesia, 1(2), pp.132-139.

Firdaus, F.F., \& Dewi, A., 2014. Evaluasi Kualitas Pelayanan Terhadap Kepuasan Pasien Rawat Jalan Peserta BPIS di RSUD Panembahan Senopati Bantul. Jurnal Universitas Muhammadiyah Yogyakarta, Yogyakarta.

Kementerian Kesehatan RI., 2008. Keputusan Menteri Kesehatan Nomor 129/Menkes/ SK/II/2008 tentang Standar Pelayanan Minimal Rumah Sakit. Jakarta: Kementerian Kesehatan RI.

Linimol, L.T., \& Nair, B.C., 2016. An Assessment of Service Quality and Patient Satisfaction in Healthcare Services Using SERVQUAL Model. Journal of Chemical and Pharmaceutical Sciences, 9(4).

Musramadoni., 2016. Pelaksanaan Badan Penyelenggaraan Jaminan Sosial (BPIS) Kesehatan di Rumah Sakit Umum Daerah (RSUD) dr. Rasidin Padang Berdasarkan Undang-Undang Nomor 24 Tahun 2011 tentang Badan Penyelenggara Jaminan Sosial. Jurnal Ilmu Hukum Universitas Tamansiswa, Padang.

Pouragha, B \& Zarei, E., 2016. The Effect of Outpatient Service Quality on Patient Satisfaction in Teaching Hospital in Iran. Mater Sociomed, 28(1), pp.21-25.

Sondari, A., \& Raharjo, B.B., 2017. Tingkat Kepuasan Pasien Rawat Jalan Peserta Jaminan Kesehatan Nasional (JKN). HIGEIA, 1(1), pp.15-21.

Sulayman, M.M., 2012. Pengaruh Dimensi Service Quality Terhadap Customer Satisfaction serta Pengaruh Customer Satisfaction dan Trust Terhadap Customer Loyalty BCA di Surabaya. Jurnal Ilmiah Mahasiswa Universitas Surabaya, 1(1).

Zaim, H., Bayyurt, N., \& Zaim, S., 2010. Service Quality and Determinants of Customer Satisfaction in Hospitals: Turkish Experience. International Business \& Economics Research Journal, 9(5). 